\title{
Types of Modality in News Item is Used in the Texts News in the Jakarta Post Newspaper
}

\author{
T. Aldilla Syahira ${ }^{1}$, T. Silvana Sinar ${ }^{2}$, Masdiana Lubis ${ }^{3}$ \\ 1,2,3 Universitas Sumatera Utara, Indonesia \\ aldilla.syahira@yahoo.com
}

\begin{abstract}
This research aimed to find out types of modality and to explain how the most dominant types of modality in news item is used in the texts news in The Jakarta Post newspaper. This research was conducted by using corpus analysis as the appropriate tool to analyze the online written text. The data were taken from the source of Jakarta Post newspaper which published online from the 1st August until 31th December 2019. The sources varied in four themes i.e. politic, education, sports and economic news. As a result, the researcher found 2 types of modality there are modalization and modulation. These types have 2 types of intermediacy on each, probability and usuality for modalization and obligation and inclination for modulation.
\end{abstract}

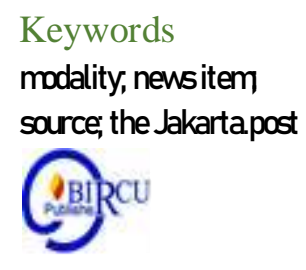

\section{Introduction}

Almost every day people use modality to communicate their messages depending on the value and degree of their choices. Aminullah (2018) stated that communication is conveying information or ideas rather than messengers to the recipient of the message, so that the recipient of the message will understand as understood by the messenger. Communication becomes a system that is formed rather than a process of interaction performed by someone with another to make a complementary relationship to every process that applies. Based on this concept emerged various forms of study existing in communication such as language communication, cultural communication, communication ethics, public communications even to emerge recent studies such as political communication, communication propaganda and various other studies about communication.

Halliday (1994:358) established three basic values which are "attached to the modal judgment: high, median and low". People make selections which modalities they choose to deliver their messages, depending on how high, median and low the value of messages.

Modality also gives an expression such as possibility, ability, obligation, permission and so on. In the entry 'modal (auxiliary) (verb)' we read: “a member of a small class of verbs that have meanings relating to modality, that is to such concepts as possibility or permission (can, may), obligation, necessity or likelihood (must,should), prediction, intention or hypothesis (will, would)"(Leech, 2006:64).

This study is concerned with the analysis of modalities that found in the news item genre of the Jakarta Post. The language of news in Jakarta Post newspaper has certain characteristic of its own. Newspaper language is relatively formal, impersonal and taking possession to influence the readers. To influence the readers, The Jakarta Post provides the vary news $b$ using the modalit in those news texts. 
Modality provides types and values to understand how news items work in the text. The researcher saw a lot of use of modality in the news of Jakarta Post newspaper since the sentences or comments conveyed by the person witnessed an incident for the news. From modality it can be shown the perspective and consideration of uncertainty things, or personal opinion that could be expressed in the meaning of clause mainly in the news delivered through the 'Source' can influence the reader of what is said.

As stated Van Dijk (1987), there may be systematic differences between the ways that news actors of different statuses are quoted. A quotation may signal truthfulness and esteem in the case of the more powerful but uncertainty and doubt as far as the less powerful are concerned. The goal of communication between the 'Source' and the reader is successfulby paying attention toward the using of proposition and proposal found in indirectly establish modalities. Hence, modality is important to be analyzed.

\section{Review of Literatures}

The structure of a news item genre consists of Headline, Summary of Event, Background and Source. Headline News or often known as the headlines as the first element of the news item has the strategic location and contain certain emphasize, then Headline News can be the initial reading material for mass media reader, even the Headline is often being an indicator of assessments about the important topics. The Summary of Event contains with the abstract of the event or phenomena that will be reported through the news item, the Background elaborates about what happened in the event, to which this event happened and in what circumstances this event happened, and the Source contains a comment given by a person or participant, or authority on the subject as a tool of journalistic interpretation used to corroborate information in news event (Pardiyono, 2007).

For humans language is a very important communication tool, with that language, people can convey various inner news, thoughts, and hopes to fellow humans. With that language also people can receive and convey all knowledge, hopes, and messages. Because of the position of such language, language is encountered in all areas of human life, including in the field of advertising. Communication activities not only involve a participant, but also involve other participants. In order for participants to understand the intentions of each other's speech, the research must have good cooperation (Suharyanto and Hidayat, 2018).

Using language appropriately does not mean mere correct phonology, morphology, syntax, and semantics, but involves pragmatic knowledge or, to be more specific, cultural knowledge to avoid misunderstandings or communication breakdowns. Misunderstandings caused by grammatical mistakes are more tolerated than those rooted in different assumptions (Hyde, 1998). This raises an issue at the language pedagogy level, which is more than grammatical or structural accuracy. (Vu, 2017, p.1). Barron, (2003); Hymes, (1972); Widdowson, (1992), argued that "with the rapid economic development and further implementation of the reform and opening policy, the role of English, especially communicative competence in English, which refers to both the knowledge of a language and the ability to use that knowledge in social interactions, has become more and more important in the daily life of people around the world in general (Ibrahim and Maniam, 2020).

Modality is the intermediate degree between positive and negative poles (Halliday, 1994:88). Modality is a resourceful linguistic device, and the use of modality by any speakers is purposive and implies a consequence both for the utterance itself and the 
listeners or readers. The implication of modality use depends on some variables. Halliday proposes three variables: system of type, orientation, and value (1994:356-358).

In this study, the researcher used Antconc to analyze the texts. As according to Anthony (2004): "AntConc is a freeware application, making it ideal for individuals, schools or colleges with a limited budget, and runs on both Windows and Linux/Unix based systems. Although it has a freeware license, it includes an easyto-use, intuitive graphical user interface and offers a powerful concordancer, word and keyword frequency generators, tools for cluster and lexical bundle analysis, and a word distribution plot".

Halliday (2014:88) stated that the corpus was originally conceived as a tool for the study of grammar: Quirk referred to his Survey as 'an NED of English usage', and it played a fundamental part in the preparation of A comprehensive grammar of the English language (Quirk, Greenbaum, Leech \& Svartvik, 1985).

\section{Research Methods}

\subsection{Research Design}

The method of this study is qualitative. According to Miles, Huberman and Saldana (2014:1), qualitative data are a source of well-grounded, rich descriptions and explanations of human processes. With qualitative data, one can preserve chronological flow, see which events led to which consequences, and derive fruitful explanations. In this study qualitative research is conducted through a naturalistic setting to investigate the everyday organizations of Jakarta Post newspaper.

\subsection{Participants}

The data of this research are in the form of modality processed through the corpus. The source of the data is Jakarta Post documentation from the website address from https://thejakartapost.com/ which consisted of 2218 sources. And the data of this research are the sentences consist of modality.

\subsection{Instruments}

Qualitative data are a source of well-grounded, rich descriptions and explanation of human process. (Miles and et al, 2014:1). In this research, there are several steps to collect the data:

1. Downloading the text to be analyzed fromhttps://www.thejakartapost.com.

2. Reading and examining carefully the texts.

3. Identifying modality from the headlines.

4. Classifying the topics of the headlines.

5. Collecting the data and changing into txt form.

6. Enter all existing data obtained into antconc software.

7. Processing the data when have been obtained by using antconc software.

8. Register sentences containing modality from the texts.

Data display defines as an organized, compressed assembly of information that allows conclusion drawing and action (Miles, Huberman and Saldana's, 2014:31). After collecting the data and being condensation or coded the data, the writer is going to display the data in the form of table. The data in the form of table uses modality theory is proposed by Halliday. So the reader can be helped. Because of looking at the analysis in the table is simpler. To answer the previous problem in background, the writer finds out the most dominant type and value of modalities that is applied into 
percentage of formula as proposed by Bungin (2001:189). The formula and the sample of analysis in the form of table are follows:

$$
\mathrm{N}=\frac{f(x)}{n} \times 100 \%
$$

More details:

$\mathrm{N} \quad=$ Percentage of types

$f(x)=$ Total types frequency of the sub category

$n \quad=$ Total types of all categories

\subsection{Data Analysis}

The technique of data analysis in this research is focused on four characteristics, according to Miles, Huberman and Saldana (2014) those are Data Collection, Data Condensation, Data Display and conclusion (drawing/verifying).

\subsection{Results}

\section{Results and Discussion}

Before analyzing the types of modality found in the Source of the News Items, the word frequency of the Source should be recapitulated in economic, education, politic and sport News that are characterized the modality expressions that instantiated them in the news items, as shown in the following table.

Table 1. Word Frequencies of Source in News Items Genre in Jakarta Post

\begin{tabular}{c|c|c|c|c|c|c|c|c}
\hline Rank & $\begin{array}{c}\text { Frequency of } \\
\text { Economic } \\
\text { News }\end{array}$ & Word & $\begin{array}{c}\text { Frequency of } \\
\text { Education } \\
\text { News }\end{array}$ & Word & $\begin{array}{c}\text { Frequency } \\
\text { of Politic } \\
\text { News }\end{array}$ & Word & $\begin{array}{c}\text { Frequency } \\
\text { of Sports } \\
\text { News }\end{array}$ & Word \\
\hline 1. & 1154 & The & 1141 & The & 1845 & The & 952 & The \\
2. & 536 & To & 600 & To & 620 & To & 445 & To \\
\hline 3. & 401 & In & 362 & And & 505 & Said & 291 & I \\
\hline 4. & 392 & Said & 353 & Of & 462 & Of & 286 & In \\
\hline 5. & 382 & And & 344 & In & 434 & And & 244 & Said \\
\hline 6. & 377 & Of & 339 & Said & 375 & Is & 233 & A \\
\hline 7. & 292 & We & 308 & A & 371 & A & 229 & And \\
\hline 8. & 246 & A & 243 & That & 351 & In & 218 & We \\
\hline 9. & 223 & That & 235 & We & 316 & That & 196 & He \\
\hline 10. & 221 & Is & 230 & I & 306 & He & 187 & Of \\
\hline 11. & 191 & On & 215 & Is & 286 & We & 163 & Is \\
\hline 12. & 189 & Will & 199 & It & 248 & S & 161 & For \\
\hline 13. & 174 & Are & 176 & For & 241 & On & 158 & It \\
\hline 14. & 174 & He & 170 & On & 215 & Be & 139 & That \\
\hline 15. & 171 & Be & 167 & They & 206 & It & 129 & As \\
\hline 16. & 169 & For & 143 & S & 206 & Will & 117 & Have \\
\hline
\end{tabular}


Modality correspondingly has two types: the modalization and modulation. Modalization involves the validity of information and modulation is associated with the willingness of a speaker in offer and the responsibility on the hearer or reader in command. In this analysis, the recapitulation of modality in the Source can be seen in the following table.

Table 2. Frequencies of Modality Types in News Item Genres

\begin{tabular}{c|c|c|c|c|c|c|c|c}
\hline \multirow{2}{*}{ News } & \multicolumn{8}{c}{ Types of Modality } \\
& \multicolumn{9}{|c}{ Modalization } & \multicolumn{3}{c}{ Modulation } \\
\cline { 2 - 9 } & Prob & \% & Usu & \% & Obl & \% & Incli & \% \\
\hline Economics & 4 & 13.33 & 16 & 53.33 & 4 & 13.33 & 6 & 20 \\
Educations & 8 & 12.12 & 52 & 78.78 & 4 & 6.06 & 2 & 3.03 \\
Politics & 9 & 15.51 & 32 & 55.17 & 7 & 12.06 & 10 & 17.24 \\
Sports & 2 & 5.12 & 31 & 79.48 & 5 & 12.82 & 1 & 2.56 \\
Total & 23 & $11.91 \%$ & 131 & $67.87 \%$ & 20 & $10.36 \%$ & 19 & $9.84 \%$ \\
\hline
\end{tabular}

In this research, the researcher found these 2 (two) types of modality. Usuality of modalization is found dominantly used in the whole of data with the figure of $67,87 \%$ and followed by probability with the figure $11,91 \%$. In other words, modalization is the most used in 4 (four) kinds of text news in Jakarta Post.

\subsection{Discussion}

From the results, the researcher found out that in the Source of news items genre 'usuality' of modalization is the most frequent modality use in economics, politics, educations and sports news items of Jakarta Post newspaper. Usuality has a total frequency of $67,87 \%$. On education news, usuality with the finite modal operator "always" has a total frequency of $78,78 \%$. Usuality type also dominates on economics, political and sports news. The word "always" in usuality expresses something that is done or felt by someone almost all the time. In the table, we can see the type of usuality is the most occurrence, it expresses the information the news delivered by the source is often to be happened in time or future. As far as it is concerned, 'usuality' has been used by journalists when they want to express judgments to the frequency with which something happening or being.

Furthermore in modulation, the most occurrences is "obligation" in economic news the word "required" is the most often appeared. Source informs that skilled labour is something needed by MRO. Service is to prioritize customer satisfaction. Customer satisfaction can be achieved with sufficient skilled labor. In education news, the word "allowed" is the most dominant modality appeared. Source want to show that female circumcision is allowed to be preserved for religious reasons. But on the condition, it is not allowed to injure the child's genitals. Furthermore in politic news, the word "allowed" still the most often appeared. Source wants to convey that he had permission to tell people that someone was asking him to help someone in the defense sector. Unlike the three previous news texts, "supposed" is the most modality appeared in sports news. The use of the word "supposed" informs that something expected did not happen. Source wants to tell readers the training is planned to start in 2017. However, there were things prevented the start of the training, so that the training would start in this year. 


\section{Conclusion}

The 4 texts news in Jakarta Post consists of 2216 total sources, 8057 total word types and 75285 word tokens. The findings got 2 types of modality used in Jakarta Post newspaper, there are modalization and modulation. These types have 2 types of intermediacy on each, probability and usuality for modalization and obligation and inclination for modulation. Economics has 53,33\% usuality, educations has 78,78\% of usuality, politics has $55,17 \%$ of usuality, sports has $79,48 \%$.

\section{References}

Aminullah, M. (2018). Theory of Alamin (A Formation of Universal Communication Formula). Budapest International Research and Critics Institute-Journal (BIRCIJournal). P. 162-181.

Bungin, Burhan. 2001. Metodologi Penelitian Sosial: Format-Format Kuantitati dan Kualitatif. Surabaya: Airlangga University Press.

Halliday, M.A.K \& Matthiessen, C. M.IM. (2014). Halliday's Introduction to Functional Grammar. London: Arnold.

Halliday, M.A.K. (1994). An Introduction A Review Article of the Pragmatics-BasedCurriculum in EFL Context: Focus on the Curriculum in Iraq to Functional Grammar. London: Arnold. Budapest International Research and Critics in Linguistics and Education (BirLE) Journal. P. 1065-1073.

Ibrahim, A., and Maniam, M. (2020).

Leech, Geoffrey. (2006). A Glossary of English Grammar. Edinburgh: Edinburgh University Press. Miles, M.B, Huberman, A.M, \& Saldana (2014). Qualitative Data Analysis - A Methods Sourcebook. Edition 3. Thousand Oaks, CA: Sage Publications.

Pardiyono. (2007). PastiBisa! Teaching Genre-Based Writing. Yogyakarta: CV. Andi Offset.

Suharyanto, A., and Hidayat, T.W. (2018). Revealing Medan's Chinese Ethnic Identity in Advertising Grief at Harian Analisa Newspaper. Budapest International Research and Critics Institute-Journal (BIRCI-Journal). P. 83-92.

Van Dijk, Teun A. (1987). Critical News Analisys.Introductory paper for the Instituto de semiotica y comunocacion. 